\title{
Reconstruction of long-term aerosol optical depth series with sunshine duration records
}
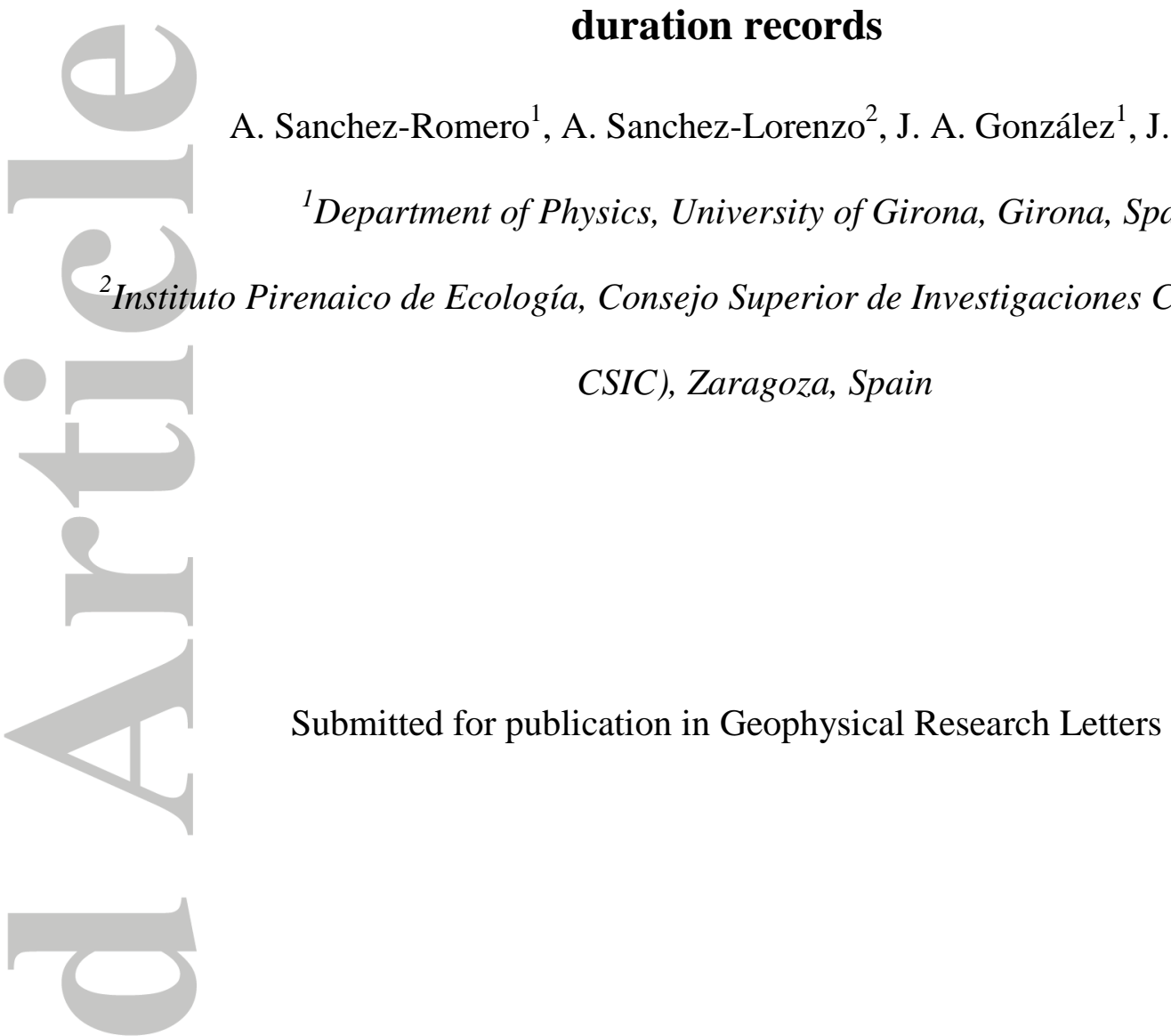

Corresponding author:

Alejandro Sanchez-Romero

Department of Physics

University of Girona

C/ M. Aurèlia Campmany, 63, Campus Montilivi, EPS II

17071 Girona (Spain)

Email: alejandro.sanchez@udg.edu

\footnotetext{
This article has been accepted for publication and undergone full peer review but has not been through the copyediting, typesetting, pagination and proofreading process which may lead to differences between this version and the Version of Record. Please cite this article as doi: $10.1002 / 2015 G L 067543$
} 


\section{Abstract}

We report the suitability of sunshine duration (SD) records as a proxy for the reconstruction of atmospheric aerosol content, for which little information exists, especially prior to the 1980s. Specifically, we have treated cloudless summer days in 16 stations throughout Spain. For almost all sites we find statistically significant relationships between aerosol optical depth (AOD), and daily SD. The correlation coefficient presents a mean value of -0.72 , and slope values of the linear regressions are within the range $[-0.11,-0.36]$. The relationships are used to generate AOD series back to the 1960s (to the 1920s for Madrid). These reconstructed series show an increase in AOD from the mid-1960s to the 1980s, followed by a decrease until the present, in agreement with changes in anthropogenic aerosol emissions and with opposite trends of solar irradiance. The method can be used to reconstruct AOD from the late $19^{\text {th }}$ century at many stations worldwide.

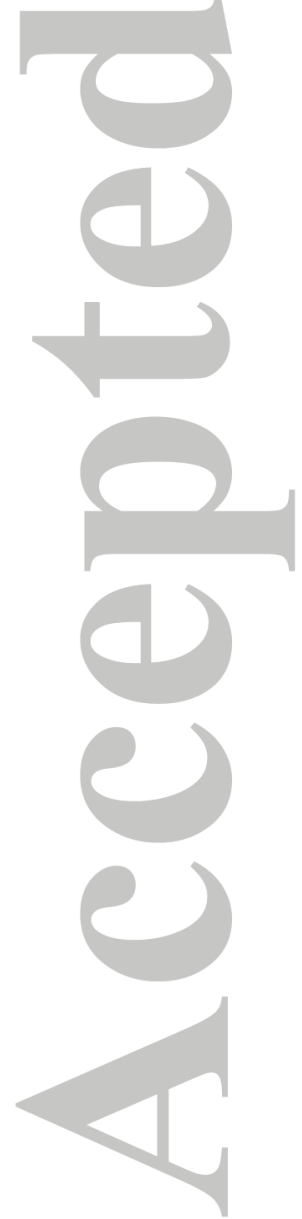




\section{Introduction}

Atmospheric aerosols play a key role in the global energy balance, and therefore in modulating climate through its direct effect on radiation [e.g., Charlson et al., 1992; Hansen et al., 1997] and its indirect effects associated with interaction with clouds [e.g. Twomey, 1977; Ramanathan et al., 2001; Rosenfeld et al., 2014]. Determining the evolution of the atmospheric aerosol load in the past is thus of capital importance with regard to quantifying its effects on radiation and other climatic variables, and consequently to furthering our knowledge of the global climate system [Hartmann et al., 2013].

One of the major pieces of evidence supporting the crucial role played by atmospheric aerosol in modulating surface solar radiation is provided by the dimming and brightening phenomenon [Stanhill and Cohen, 2001; Wild, 2009]. The changes in atmospheric transmissivity since the mid- $20^{\text {th }}$ century, which result from variations in anthropogenic aerosol emissions, are considered to constitute the main factor causing the trends observed in surface solar radiation [Wild, 2009, 2012]. The limited availability of systematic measurements hinders the study of the evolution of surface solar radiation before the dimming-brightening period (i.e., 1960s): these only started subsequent to the 1957-1958 International Geophysical Year, becoming worldwide much more recently.

Furthermore, widespread quantification of the aerosol load in the atmosphere (or at least of its radiative characteristics) had not commenced until the late 1970 s, with the development of ground and satellite-based instruments. The aerosol series obtained by satellite were started in 1978 with the Nimbus platform, while spectral sun photometers also started to be used in the 1970s [Shaw et al., 1973; Voltz, 1974]. These old datasets often present inhomogeneities and/or conflicting results at the beginning [Cermak et al., 2010]. In addition, they had a low 
spatial resolution, while the limited number of ground-based measurements prevented them from being useful for fully explaining the effect of aerosols on climate.

At present, the global network of Cimel sun photometers called AErosol RObotic NETwork (AERONET) is considered to be the main reference for measuring aerosol characteristics from the ground [Holben et al., 1998; Dubovikl and King, 2000], but most of the stations were established after the 1990s. Moderate Resolution Imaging Spectroradiometer (MODIS) and Multi-angle Imaging Spectroradiometer (MISR) [King et al., 1992; Diner et al., 1998] constitute the current satellite instruments most commonly used for aerosol observation, but also started measuring at the end of 1990s. They provide global coverage, but with low temporal resolution as compared to ground based observations. The latter are assumed to give more accurate aerosol retrievals, and usually involve measurements of direct solar radiation in distinct spectral bands.

Herein we advocate the use of sunshine duration (SD) as a proxy of aerosol optical depth (AOD), and hence of atmospheric turbidity for studying the evolution of the atmospheric aerosol load in the past. According to the WMO [2008], the SD for a given period is defined as the sum of the sub-periods for which direct solar irradiance exceeds $120 \mathrm{Wm}^{-2}$. One of the instruments used to measure SD is the Campbell-Stokes sunshine recorder (CSSR). It was invented in the late $19^{\text {th }}$ century to provide a measurement of the duration of bright sunlight by means of a burn mark on a piece of specially treated cardboard [Stanhill, 2003; SanchezLorenzo et al. 2013]. Although in recent years some stations have changed CSSR for new models of automatic sunshine recorders, the long record of SD measurements endow them with remarkable historical value; their series are much longer than those of aerosol and surface solar radiation.

The effect of atmospheric turbidity (caused by the presence of aerosol) on SD has been 
addressed in several studies [for a review, see Sanchez-Romero et al., 2014]. Cohen and Kleiman [2005] observed that on some cloudless mornings (afternoons), the sun cannot be seen after the previously calculated sunrise (before the sunset), so the length of the day is apparently shortened due to a higher aerosol content. Recently, Magee et al.[2014] observed that SD variability is associated with a wide variety of natural and anthropogenic processes (e.g. industrial activity and regional air quality). In this direction, some authors [Jaenicke and Kasten, 1978; Helmes and Jaenicke, 1984, 1986; Horseman et al., 2008] claim that aerosols reduce daily SD due to their effect at low solar elevations (i.e. at the beginning and the end of the day): a high aerosol content can reduce the incident direct solar irradiance and, in consequence, the burn time is reduced on the CSSR cards (or the time reaching the threshold irradiance in the automatic devices).

We assume that SD can be used as a proxy for AOD, which may be useful for reconstructing aerosol-related series in time and then for explaining long-term aerosol effects. We test this hypothesis with data from some stations on the Iberian Peninsula (southern Europe) and in the Canary Isles.

\section{Data and methods}

We used data from 16 stations of the Spanish Meteorological Agency (AEMET) and 16 stations associated with AERONET and distributed throughout Spain (Figure 1, Table 1). It should be noted that two stations are located in the Canary Isles, much further south of the Iberian Peninsula, facing the coast of West Africa. At all these selected sites, an AEMET station is close to the AERONET station, or is even located in the same place. The mean horizontal distance for each pair of stations is $12.6 \mathrm{~km}$ (with a maximum of $42.3 \mathrm{~km}$ ). 
Daily records of SD (in hours) are available from the AEMET stations, mostly measured by CSSR, although some stations have recently changed to an automatic sensor (Table 1). The uncertainty of this measurement is $0.1 \mathrm{~h}$ [WMO, 2008]. We calculated the SD fraction, which is the ratio of SD to the total length of the day defined as the time from sunrise to sunset. In addition, total cloud cover (TCC) records were obtained for these stations. These data correspond to ground level visual observations measured in oktas, and are available for observations taken three times a day (at 7, 13 and 18 UTC). In order to screen out the clouds, we only considered cloudless days, i.e. days on which mean daily TCC from the 3 daily observations is rounded to 0 oktas (a maximum of one observation with a maximum of 1 okta is therefore allowed).

The AERONET stations provide mean daily values of AOD in several channels $(440,500$, 675 and $870 \mathrm{~nm}$ ). Specifically, we used in this study mean daily values of AOD in the 440 $\mathrm{nm}$ channel (this channel is available at all sites), $\mathrm{AOD}_{440}$, by using the cloud-screened and quality-assured level 2.0 data. The uncertainty of AOD in this channel is 0.02 [Holben et al., 1998]. The period of time with availability of SD, TCC and AOD data is also shown in Table 1 for each pair of stations. This period depends mainly on the starting date of the AERONET station, as most of the SD and TCC data from AEMET started prior to the 1980s. It should be noted that we use at least two years of data for each site.

We first explored the relationship between $\mathrm{AOD}_{440}$ and SD fraction for the summer months (June, July and August), as this season presents the maximum number of cases with clear-sky conditions and the lowest effect of dew or precipitation on the glass sphere or on the CSSR cards [Sanchez-Romero et al., 2014]. In addition, higher amounts of aerosols are sometimes present in this region during summer, which increases the range of AOD values employed [Bennouna et al., 2013]. Moreover, for the range of latitudes covered by the studied stations (from $28^{\circ}$ to $43^{\circ}$ ) the apparent trajectories of the Sun in the sky (which has some effect on the 
expected and observed SD), are very similar in this season. Results of this part of the study are reported in Section 3.1.

In order to study the long-term changes of AOD in Spain, we selected those sites with SD series that proved to be homogeneous. Specifically, the temporal homogeneity of each of the 16 SD series was checked by means of the Standard Normal Homogeneity Test (SNHT) [Alexandersson and Moberg, 1997]. Our approach rejects the a priori assumption of nonexistence of homogenous reference series, and consists of testing each of the 16 series against the others, normally in subgroups of the highest correlated series (i.e., using as reference the series that present $\mathrm{R}>0.7$ ). In short, the SNHT test derives a statistic $\mathrm{T}$ where changes in the standardized difference series between candidate and reference time series over the whole period are calculated. Large changes in the mean values before and after a time step, which indicate the possibility of breaks in the time series, provide high values of T. For further details, see e.g. Alexandersson and Moberg [1997]. Only seven series proved to be homogeneous: Zaragoza, Badajoz, Madrid, Murcia, Santa Cruz de Tenerife, Palma de Mallorca, and Almería. The other series show evidence of inhomogeneity with at least one significant break $(p<0.05)$ since the 1960s, except for Izaña, where the only inhomogeneity is detected around 1953. Consequently, for the subsequent analyses we used only the seven homogeneous series, as well as the records from Izaña since the mid-1950s.

Subsequently, since the goal is to be able to estimate AOD from SD data, we fitted daily $\mathrm{AOD}_{440}$ respect to daily SD for the summer cloudless days at these eight sites. We used here the orthogonal-distance regression method weighted by the measurement uncertainty ratio. The obtained relationships were then applied to the historical data of SD, and the daily series of estimated $\mathrm{AOD}_{440}$ were converted into summer values, by averaging all daily values of each summer. In order to detect a general signal in the mean anomalies over Spain that is not 
affected by local conditions (e.g., differences in absolute mean values), we computed the relative anomalies of estimated AOD for each station with respect to the 1971-2000 period (which is common for all eight series), and then averaged all available anomaly series. This also reduces the bias resulting from the fact that the number of available series varies over time. Results of this part of the study are shown in Section 3.2.

\section{Results and Discussion}

\subsection{Effect of AOD on SD}

Figure 2 shows the scatterplot of SD fraction versus $\mathrm{AOD}_{440}$ for eight selected cases (which are the sites having homogenous SD series that will be used in the next section to reconstruct AOD). The relationship is clearly linear, so in Table 1 we present the parameters of the linear fit between SD fraction and $\mathrm{AOD}_{440}$ for each location. The negative slopes mean that an increase in AOD causes a decrease in SD. Taking into account the uncertainties involved, and that cloudless days are selected upon only three TCC observations during each day, the correlations obtained may be considered to be remarkable. More concretely, all 16 sites treated, except Coruña, show significant correlation coefficients at a confidence level higher than $95 \%$. The weighted average (accounting for the number of points of each case) of the correlation coefficient is -0.72 . For some sites, e.g. Granada and Santa Cruz de Tenerife, the correlation coefficient is even greater (in absolute terms) than -0.9 . The different values of correlation (and of the other parameters of the regression) could be explained partially by the uncertainties in the observations used. In addition, in some cases, the AEMET and AERONET stations are quite distant, e.g. Valladolid (from Palencia) and Huelva (from El Arenosillo); or at different altitudes, e.g. Barcelona and Almeria.

Intercept values of the linear regression are close to 1 (a weighted mean value of 0.96 ), which 
agrees with the fact that for AOD (and TCC) close to 0, the SD fraction must be close to 1 (i.e., SD approaching the length of the daytime). Slope values present some variability (Table 1), even if all are negative, with a weighted (i.e., depending on the number of points used in the linear regression) mean value of -0.28 . This mean value implies a change in SD of around $3 \%$ per 0.1 units of AOD. It should be noted that even if we consider the associated uncertainty, all slope values maintain negative values. As expected, closer sites show similar slope values (Izaña and Santa Cruz de Tenerife, in the Canary Isles, and Caceres and

Badajoz, both inland locations in the West of Spain). The variability in slope values may be explained with different types of aerosol depending on the region of Spain. Different aerosol types exhibit different optical properties (that is, they have different effects on the scattering and absorption along the spectrum of solar radiation, although they may present the same $\mathrm{AOD}_{440}$ value) and, consequently, could affect SD measurement in a different manner. We speculate that the different classes of particles found in Spain [Pereira et al., 2011; Sicard et al.,2011; Obregón et al., 2014], could affect SD in different ways: the high slope values in Table 1 could correspond to the presence of desert dust (from the Sahara desert and from arid regions of the Iberian Peninsula) and marine aerosol (southern and Canary Isles sites), while dominant continental aerosol could be related to lower slopes (Mediterranean and western sites).

The effect of AOD on SD provided herein by means of empirical observations is also supported by theoretical results. Specifically, we studied the effect of AOD upon SD using the Santa Barbara DISORT Atmospheric Radiative Transfer model (SBDART) [Ricchiazzi et al., 1998]: a series of runs was performed with different aerosol conditions, including type (rural, urban, oceanic, and tropospheric aerosol) and AOD (from 0 to 1). The model was run in order to find the value of solar height needed for the direct solar irradiance to reach 120 $\mathrm{Wm}^{-2}$, depending on aerosol conditions, for a certain unspecific site located at latitude of 
$40^{\circ} \mathrm{N}$ (mean latitude of the Iberian Peninsula). This solar height is then transformed into time by simple astronomical relations, and an SD fraction depending on aerosol conditions is finally established. The range of slope values obtained in the regression between such simulated SD fraction and AOD is compatible with those shown in Table 1. Low values of the slope were obtained for tropospheric aerosol $(-0.13)$, whereas increasingly higher values were obtained for rural $(-0.17)$, urban $(-0.20)$, and oceanic aerosols $(-0.30)$. The concrete values of slope depend on the range of AOD values used in the linear regression between relative $\mathrm{SD}$ and $\mathrm{AOD}_{440}$.

\subsection{Reconstruction of AOD series}

The coefficients of the fit between $\mathrm{AOD}_{440}$ and SD fraction (the latter used as the predictor variable), performed with the orthogonal-distance method, for the eight selected sites, are given in Table 1 . These fits are then used to estimate daily $\mathrm{AOD}_{440}$ for all summer cloudless days since the beginning of the corresponding SD and TCC series (except for Izaña, where we start after the break detected in 1953). It should be noted that the fits for the other sites could be derived as well, but they would be useless as we are not intending to reconstruct AOD series from inhomogeneous SD data. For the eight selected sites and for the period used to develop the fit, the root mean square deviation (RMSD) between daily estimated and measured $\mathrm{AOD}_{440}$ is also given in Table 1. The agreement between estimations and measurement is further confirmed when comparing the averaged summer values (for all sites together, see Figure S1), with a RMSD of 0.035 .

In Figure $3 \mathrm{~A}$ we represent the evolution of the mean relative anomalies (with respect to a mean value of 0.26 for the $1971-2000$ period) of estimated $\mathrm{AOD}_{440}$ for summer and for the eight homogenous series, during the period 1961-2014. See Table S1 for the absolute values of the evolution of mean summer estimated $\mathrm{AOD}_{440}$. It is worth noting that the smoothed 
evolution of the AOD is very similar if we use only data from the Canary Isles sites (Figure S2A) or the other sites (Iberian Peninsula and Mallorca, Figure S2B). This means that the decadal evolution observed does not reflect local anomalies, but is quite representative of the whole region. There is a clear increase in AOD from the mid-1960s to the 1980s, with a maximum during the 1982-1984 period. A decrease in AOD then becomes apparent from the 1980 s to the 2010s, which almost results in a recovery of AOD levels to those of the mid1960s. The linear trend, estimated over the whole 1961-2014 period, is not statistically significant at the $95 \%$ confidence level as assessed by means of the Mann-Kendall nonparametric test. If the whole period is subdivided into the 1961-1984 and 1985-2014 subperiods, both linear trends are significant positive (32\% per decade) and negative $(-22 \%$ per decade), respectively. The latter is in agreement with Ruckstuhl et al. [2008] and Chiacchio et al. [2011], who found AOD decreases of about 60\% since the 1980s in Europe.

In order to validate our approach, we compared our $\mathrm{AOD}_{440}$ estimation for Izaña during the 1955 to 2010 period (as an inhomogeneity can be observed around 1953) with AOD at 500 nm obtained by García et al. [2015]. They estimated the long-term AOD time series at Izaña using Artificial Neural Networks techniques and, as input parameters, in-situ meteorological observations (visibility, SD, TCC, relative humidity and temperature) and day of year. Both methods agree very well, as they present a minimum $(\sim 0.1)$ around 1955 , and then an increase in AOD until $1982(\sim 0.3)$, followed by a decrease until the present $(\sim 0.1)$. The peaks of 1968 and 1982 are also in concordance. So, our simpler method (which uses only SD and TCC data) provides results similar to those of that more complex technique.

The results shown in Figure 3A are also in agreement with the dimming and brightening phenomenon described elsewhere for the Iberian Peninsula [Sanchez-Lorenzo et al., 2009, 2013a; Román et al., 2014] and Europe [Sanchez-Lorenzo et al., 2015], while the continued decrease in AOD, even after the 2000s, is in line with the results shown in Mateos et al. 
[2014]. In addition, the maximum values of AOD during the summers of 1982-1984 are in concordance with the eruption of the El Chichón volcano (spring 1982). The eruption of Pinatubo (summer 1991) was bigger than that of El Chichón, but its signal is not clearly visible in Figure 3A; taking into account that an increase of AOD decreases SD, other studies of SD series in Europe also found a stronger signal of the El Chichón compared with that of the Pinatubo erupted [Sanchez-Lorenzo et al., 2009; Manara et al., 2015]. Further research is needed about other causes associated with the observed trends of AOD, especially in relation to the trends of dust over the region. Indeed, it is intriguing that the maximum in the early 1980s, as well as the decadal variability of AOD since 1960, is in agreement with the drought in the Sahel region [e.g. Held et al., 2006], which is one of the main source areas of dust [Prospero, 2014], especially over the Mediterranean region. In addition, when only the Canary Isles sites are considered (Figure S2A), the eruptions of El Arenal and Fernandina Island volcanoes (summer 1968) are also visible [García et al., 2014], whereas they are unappreciable at the Iberian Peninsula stations. Finally, a certain amount of the aerosol evolution could also be explained by the trend of anthropogenic emissions in Western Europe [Stern, 2006; Streets et al., 2009; Nabat et al., 2014; Turnock et al., 2015].

The evolution of AOD should be noticeable in the surface solar radiation measurements in the region. According to Sanchez-Lorenzo et al. [2013a], summer global solar radiation on the Iberian Peninsula increased at a rate of $6.5 \mathrm{Wm}^{-2}$ per decade over the $1985-2010$ period, i.e. $17 \mathrm{Wm}^{-2}$ during the whole period. The decrease in cloud cover in summer during this period was almost negligible and statistically non-significant [Sanchez-Lorenzo et al., 2012], i.e. cloudiness played an unimportant role in the variation in summer radiation. We have calculated how the temporal variability of AOD found with our method would affect the temporal variability of solar irradiance. To this end, once again we used a radiative model (SBDART) to calculate the daily mean irradiance for a characteristic summer day, with high 
and low conditions of aerosol content. These are defined as $20 \%$ higher and $30 \%$ lower than the mean value of the period of reference 1971-2000 (see red line in Figure 3A). The differences between daily mean irradiances for low and high aerosol levels are around 10-23 $\mathrm{Wm}^{-2}$ (depending on the aerosol type). In conclusion, these results demonstrate the suitability of our estimated AOD evolution and confirm that aerosols may have played an important role in the brightening over Spain, despite the fact that there is still some discussion regarding the relative importance of natural and anthropogenic aerosols on the total aerosol content.

Finally, the reconstruction of AOD for Madrid is presented in Figure 3B. SD and TCC data have been available since the 1920s (specifically, in the Madrid Retiro station, for the 19202007 period). It should be noted that Madrid Retiro no longer has SD records in recent times in which AOD measurements are, however, available. Nevertheless, this observatory is close to the Madrid Cuatro Vientos station (Table 1) which presents very similar values of SD $(\mathrm{R}>0.9)$. Consequently, we used the expression derived from the latter station (Table 1) to convert the SD fraction in Madrid Retiro into $\mathrm{AOD}_{440}$. It is worth noting that the Madrid Retiro SD series has proven to be homogeneous since the 1920 s following verification by means of the SNHT test. Figure 3B shows that the AOD has a tendency to a decrease from the 1920 s to the mid- $20^{\text {th }}$ century, especially from the mid-1940s to the late $1950 \mathrm{~s}$. This trend is in line with the early brightening phenomenon reported in some regions of Europe, detected by means of SD and solar radiation series, especially from around the 1930s to the 1950s [Sanchez-Lorenzo et al., 2009, 2015; Founda et al., 2014; Matuszko, 2014; Manara et al., 2015]. Although there is no definitive explanation of this aerosol reduction and of the early brightening phenomenon, a possible cause involves the observed decrease in black carbon emissions since the early $20^{\text {th }}$ century [McConnell et al., 2007]. 


\section{Conclusion}

We studied the relationship between AOD and daily SD for cloudless days and for some stations in southern Europe with the aim of performing a long-term reconstruction of AOD. We found a negative correlation with some spatial variability (including cases with correlation coefficients higher than -0.90 on a daily basis). The reconstructed AOD series are compatible with the dimming and brightening phenomenon: the increase in AOD from the mid-1960s to the 1980s is followed by a decrease until the present. A reconstructed AOD series starting in 1920 is also presented for Madrid, where a decrease in AOD from the mid1940s to 1960 is observed. This is compatible with the early brightening phenomenon observed in other parts of Europe.

As a vast network of instruments exists that enables AOD to be measured, as well as SD and TCC measurements since the late $19^{\text {th }}$ century, this type of study can be performed in other parts of the world in order to provide more information on changes in aerosol concentration in the atmosphere, especially prior to the 1980s. In addition, as the burn width in CSSR bands has been associated with direct solar irradiance [Horseman et al., 2013; Sanchez-Romero et al., 2015], in a future study we intend to relate burn width to aerosol load at sub-daily resolution.

\section{Acknowledgements}

This research was supported by the Spanish Ministry of Economy and Competitiveness projects NUCLIERSOL (CGL2010-18546) and NUBESOL (CGL2014-55976-R). The first author enjoys a grant by the FPU program (FPU AP2010-0917) of the Spanish Ministry of Education. The second author enjoys a grant from the Spanish Ministry of Economy and Competitiveness (JCI-2012-12508). We also wish to thank Juan Ramon Moreta (Coruña, Zaragoza, Madrid, Murcia and Palma de Mallorca), Victoria E. Cachorro (Palencia and El 
Arenosillo), Sara Basart and Jose M. Baldasano (Barcelona), Maria Luisa Cancillo (Caceres and Badajoz), Jose Antonio Martínez Lozano (Burjassot), Lucas Alados Arboledas (Granada), Francisco Jose Olmo (Malaga), Stefan Wilbert (Tabernas PSA-DLR), Emilio Cuevas-Agullo (Izaña and Santa Cruz Tenerife), as well as their staff for establishing and maintaining the AERONET sites used in this investigation. Finally, we would like to thank AEMET for providing us with the sunshine duration and cloudiness series. For a better dissemination of the series developed in this study, the data set will be available on ResearchGate and the Supplementary Material of this manuscript, as well as on request (alejandro.sanchez@udg.edu). Finally, we would like to thank the useful comments of the anonymous reviewers, which significantly helped to improve the manuscript.

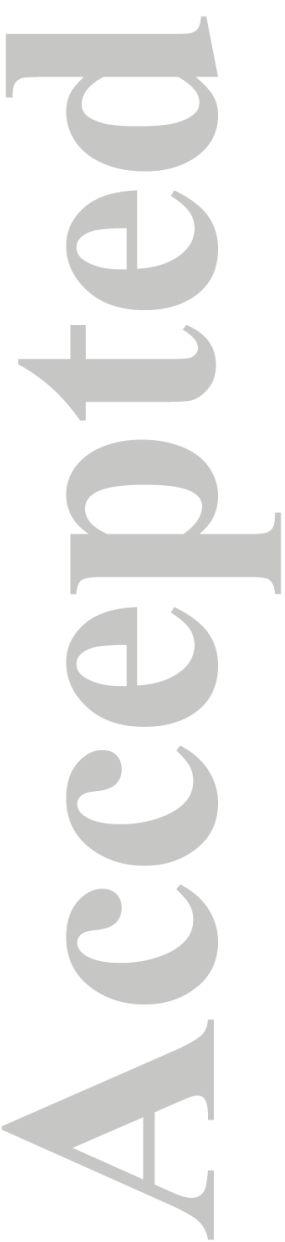




\section{References}

Alexandersson, H., and A. Moberg (1997), Homogenization of Swedish temperature data. Part I: homogeneity test for linear trends, Int. J. Climatol., 17(1), 25-34, doi:10.1002/(SICI)1097-0088(199701)17:1<25::AID-JOC103>3.0.CO;2-J.

Bennouna, Y. S., V. E. Cachorro, B. Torres, C. Toledano, A. Berjón, A. M. de Frutos, and I. Alonso Fernández Coppel (2013), Atmospheric turbidity determined by the annual cycle of the aerosol optical depth over north-center Spain from ground (AERONET) and satellite (MODIS), Atmos. Environ., 67, 352-364, doi:10.1016/j.atmosenv.2012.10.065.

Cermak, J., M. Wild, R. Knutti, M. I. Mishchenko, and A. K. Heidinger (2010), Consistency of global satellite-derived aerosol and cloud data sets with recent brightening observations, Geophys. Res. Lett., 37(21), 1-5, doi:10.1029/2010GL044632.

Charlson, R. J., S. E. Schwartz, J. M. Hales, R. D. Cess, J. A. Coakley, Jr., J. E. Hansen, and D. J. Hofmann (1992), Climate forcing by anthropogenic aerosols, Science (80-. )., 255, 423-430.

Chiacchio, M., T. Ewen, M. Wild, M. Chin, and T. Diehl (2011), Decadal variability of aerosol optical depth in Europe and its relationship to the temporal shift of the North Atlantic Oscillation in the realm of dimming and brightening, J. Geophys. Res., 116(D2), D02108, doi:10.1029/2010JD014471.

Cohen, A., and M. M. Kleiman (2005), Evidence suggesting the shortening of the day from "sunrise" to "sunset" due to global change, in 13th Intenational Workshop on Lidar Multiple Scattering Experiments, vol. 5829, edited by A. G. Borovoi.

Diner, D. J. et al. (1998), Multi-angle Imaging SpectroRadiometer (MISR) instrument description and experiment overview, IEEE Trans. Geosci. Remote Sens., 36(4), 10721087, doi:10.1109/36.700992.

Dubovikl, O., and D. King (2000), A flexible inversion algorithm for retrieval of aerosol optical properties from Sun and sky radiance measurements, J. Geophys. Res., 105(D16), 20673-20696.

Founda, D., A. Kalimeris, and F. Pierros (2014), Multi annual variability and climatic signal analysis of sunshine duration at a large urban area of Mediterranean (Athens), Urban Clim., 10, 815-830, doi:10.1016/j.uclim.2014.09.008.

García, R. D., E. Cuevas, O. E. García, V. E. Cachorro, P. Pallé, J. J. Bustos, P. M. RomeroCampos, and a. M. de Frutos (2014), Reconstruction of global solar radiation time series from 1933 to 2013 at the Izaña Atmospheric Observatory, Atmos. Meas. Tech., 7(4), 3139-3150, doi:10.5194/amtd-7-4191-2014.

García, R. D., O. E. García, E. Cuevas, V. E. Cachorro, a. Barreto, C. Guirado-Fuentes, N. Kouremeti, J. J. Bustos, P. M. Romero-Campos, and a. M. de Frutos (2015), Aerosol optical depth retrievals at the Izaña Atmospheric Observatory from 1941 to 2013 by using artificial neural networks, Atmos. Meas. Tech. Discuss., 8(9), 9075-9103, 
doi:10.5194/amtd-8-9075-2015.

Hansen, J., M. Sato, and R. Ruedy (1997), Radiative forcing and climate response, $J$. Geophys. Res., 102(D6), 6831-6864.

Hartmann, D. L. et al. (2013), Observations: Atmosphere and Surface, in Climate change 2013: The physical science basis. Contribution of working group I to the Fifth Assessment Report of the Intergovernmental Panel on Climate Change, pp. 159-254, Cambridge University Press, Cambridge, United Kingdom and New York, NY, USA.

Held, I. M., T. L. Delworth, J. Lu, K. L. Findell, and T. R. Knutson (2006), Simulation of Sahel drought in the 20th and 21st century, PNAS, 102(50), 17891-17896.

Helmes, L., and R. Jaenicke (1984), Experimental verification of the determination of atmospheric turbidity from sunshine recorders, J. Clim. Appl. Meteorol., 23, 1350-1353.

Helmes, L., and R. Jaenicke (1986), Atmospheric turbidity determined from sunshine records, J. Aerosol Sci., 17(3), 261-263.

Holben, B. N. et al. (1998), AERONET-A federated instrument network and data archive for aerosol characterization, Remote Sens. Environ., 66, 1-16.

Horseman, A., A. R. MacKenzie, and R. Timmis (2008), Using bright sunshine at lowelevation angles to compile an historical record of the effect of aerosol on incoming solar radiation, Atmos. Environ., 42(33), 7600-7610, doi:10.1016/j.atmosenv.2008.06.033.

Horseman, A. M., T. Richardson, A. T. Boardman, W. Tych, R. Timmis, and A. R. MacKenzie (2013), Calibrated digital images of Campbell-Stokes recorder card archives for direct solar irradiance studies, Atmos. Meas. Tech., 6(5), 1371-1379, doi:10.5194/amt-6-1371-2013.

Jaenicke, R., and F. Kasten (1978), Estimation of atmospheric turbidity from the burned traces of the Campbell-Stokes sunshine recorder, Appl. Opt., 17(16), 2617-2621.

King, M. D., Y. J. Kaufman, W. P. Menzel, and D. Tanre (1992), Remote Sensing of Cloud, Aerosol, and Water Vapor Properties from the Moderate Resolution Imaging Spectrometer (MODIS ), IEEE Trans. Geosci. Remote Sens., 30(1), 2-27.

Magee, N. B., E. Melaas, P. M. Finocchio, M. Jardel, A. Noonan, and M. J. Iacono (2014), Blue Hill Observatory Sunshine - Assesment of climate signals in the longest continuous meteorological record in North America, Bull. Am. Meteorol. Soc., in press, doi:10.1175/BAMS-D-12-00206.1.

Manara, V., M. C. Beltrano, M. Brunetti, M. Maugeri, A. Sanchez-Lorenzo, C. Simolo, and S. Sorrenti (2015), Sunshine duration variability and trends in Italy from homogenized instrumental time series (1963-2013), J. Geophys. Res. Atmos., 120(9), 3622-3641.

Mateos, D., A. Sanchez-Lorenzo, M. Antón, V. E. Cachorro, J. Calbó, M. J. Costa, B. Torres, and M. Wild (2014), Quantifying the respective roles of aerosols and clouds in the 
strong brightening since the early 2000s over the Iberian Peninsula, J. Geophys. Res. Atmos., 119(17), 10,382-10,393, doi:10.1002/2014JD022076.

Matuszko, D. (2014), Long-term variability in solar radiation in Krakow based on measurements of sunshine duration, Int. J. Climatol., 34(1), 228-234, doi:10.1002/joc.3681.

McConnell, J. R., R. Edwards, G. L. Kok, M. G. Flanner, C. S. Zender, E. S. Saltzman, J. R. Banta, D. R. Pasteris, M. M. Carter, and J. D. W. Kahl (2007), 20th century industrial black carbon emissions altered artic climate forcing, Science (80-. )., 317, 1381-1384.

Nabat, P., S. Somot, M. Mallet, A. Sanchez-Lorenzo, and M. Wild (2014), Contribution of anthropogenic sulfate aerosols to the changing Euro-Mediterranean climate since 1980, Geophys. Res. Lett., 41(15), 5605-5611, doi:10.1002/2014GL060798.

Obregón, M. A., A. Serrano, M. L. Cancillo, V. E. Cachorro, and C. Toledano (2014), Aerosol radiometric properties at Western Spain (Cáceres station), Int. J. Climatol., n/an/a, doi:10.1002/joc.4031.

Pereira, S. N., F. Wagner, and A. M. Silva (2011), Seven years of measurements of aerosol scattering properties, near the surface, in the southwestern Iberia Peninsula, Atmos. Chem. Phys., 11(1), 17-29, doi:10.5194/acp-11-17-2011.

Prospero, J. M. (2014), Characterizing the temporal and spatial variability of African dust over the Atlantic, PAGES Mag., 22(2), 68-69.

Ramanathan, V., P. J. Crutzen, J. T. Kiehl, and D. Rosenfeld (2001), Aerosols, climate, and the hydrological cycle, Science, 294(5549), 2119-24, doi:10.1126/science.1064034.

Ricchiazzi, P., S. Yang, C. Gautier, and D. Sowle (1998), SBDART: A Research and Teaching Software Tool for Plane-Parallel Radiative Transfer in the Earth's Atmosphere, Bull. Am. Meteorol. Soc., 79(10), 2101-2114, doi:10.1175/15200477(1998)079<2101:SARATS >2.0.CO;2.

Román, R., J. Bilbao, and A. de Miguel (2014), Reconstruction of six decades of daily total solar shortwave irradiation in the Iberian Peninsula using sunshine duration records, Atmos. Environ., 99, 41-50, doi:10.1016/j.atmosenv.2014.09.052.

Rosenfeld, D. et al. (2014), Global observations of aerosol-cloud-precipitation-climate interactions, Rev. Geophys., 52, 750-808, doi:10.1002/2013RG000441.Received.

Ruckstuhl, C. et al. (2008), Aerosol and cloud effects on solar brightening and the recent rapid warming, Geophys. Res. Lett., 35(12), n/a-n/a, doi:10.1029/2008GL034228.

Sanchez-Lorenzo, A., J. Calbó, M. Brunetti, and C. Deser (2009), Dimming/brightening over the Iberian Peninsula: Trends in sunshine duration and cloud cover and their relations with atmospheric circulation, J. Geophys. Res., 114, D00D09, doi:10.1029/2008JD011394.

Sanchez-Lorenzo, A., J. Calbó, and M. Wild (2012), Increasing cloud cover in the 20th 
century: review and new findings in Spain, Clim. Past, 8(4), 1199-1212, doi:10.5194/cp-8-1199-2012.

Sanchez-Lorenzo, A., J. Calbó, and M. Wild (2013a), Global and diffuse solar radiation in Spain: Building a homogeneous dataset and assessing their trends, Glob. Planet. Change, 100, 343-352, doi:10.1016/j.gloplacha.2012.11.010.

Sanchez-Lorenzo, A., J. Calbó, M. Wild, C. Azorin-Molina, and A. Sanchez-Romero (2013b), New insights into the history of the Campbell-Stokes sunshine recorder, Weather, 68(12), 327-331, doi:10.1002/wea.2156.

Sanchez-Lorenzo, A., M. Wild, M. Brunetti, J. A. Guijarro, M. Z. Hakuba, J. Calbó, S. Mystakidis, and B. Bartok (2015), Reassessment and update of long-term trends in downward surface shortwave radiation over Europe (1939-2012), J. Geophys. Res. Atmos., 120(18), doi:10.1002/2015JD023321.

Sanchez-Romero, a., J. a. González, J. Calbó, and a. Sanchez-Lorenzo (2015), Using digital image processing to characterize the Campbell-Stokes sunshine recorder and to derive high-temporal resolution direct solar irradiance, Atmos. Meas. Tech., 8(1), 183-194, doi:10.5194/amt-8-183-2015.

Sanchez-Romero, A., A. Sanchez-Lorenzo, J. Calbó, J. A. González, and C. Azorin-Molina (2014), The signal of aerosol-induced changes in sunshine duration records: A review of the evidence, J. Geophys. Res. Atmos., 119(8), 4657-4673, doi:10.1002/2013JD021393.

Shaw, G. E., J. a. Reagan, and B. M. Herman (1973), Investigations of atmospheric extinction using direct solar radiation measurements made with a multiple wavelength radiometer, J. Appl. Meteorol., 12, 374-380, doi:10.1175/15200450(1973)012<0374:IOAEUD>2.0.CO;2.

Sicard, M., F. Rocadenbosch, M. N. M. Reba, A. Comerón, S. Tomás, D. García-Vízcaino, O. Batet, R. Barrios, D. Kumar, and J. M. Baldasano (2011), Seasonal variability of aerosol optical properties observed by means of a Raman lidar at an EARLINET site over Northeastern Spain, Atmos. Chem. Phys., 11(1), 175-190, doi:10.5194/acp-11-1752011.

Stanhill, G. (2003), Through a glass brightly: Some new light on the Campbell-Stokes sunshine recorder, Weather, 58(1), 3-11.

Stanhill, G., and S. Cohen (2001), Global dimming: a review of the evidence for a widespread and significant reduction in global radiation with discussion of its probable causes and possible agricultural consequences, Agric. For. Meteorol., 107(4), 255-278, doi:10.1016/S0168-1923(00)00241-0.

Stern, D. I. (2006), Reversal of the trend in global anthropogenic sulfur emissions, Glob. Environ. Chang., 16(2), 207-220, doi:10.1016/j.gloenvcha.2006.01.001.

Streets, D. G., F. Yan, M. Chin, T. Diehl, N. Mahowald, M. Schultz, M. Wild, Y. Wu, and C. $\mathrm{Yu}$ (2009), Anthropogenic and natural contributions to regional trends in aerosol optical depth, 1980-2006, J. Geophys. Res. Atmos., 114(14), 1-16, doi:10.1029/2008JD011624. 
Turnock, S. T. et al. (2015), Modelled and observed changes in aerosols and surface solar radiation over Europe between 1960 and 2009, Atmos. Chem. Phys., 15(16), 9477-9500, doi:10.5194/acp-15-9477-2015.

Twomey, S. (1977), The influence of pollution on the shortwave albedo of clouds, J. Atmos. Sci., 34, 1149-1152.

Voltz, F. E. (1974), Economical multispectral sun photometer for measurements of aerosol extinction from $0.44 \mu \mathrm{m}$ to $1.6 \mu \mathrm{m}$ and precipitable water, Appl. Opt., 13, 1732-1733.

Wild, M. (2009), Global dimming and brightening: A review, J. Geophys. Res., 114, D00D16, doi:10.1029/2008JD011470.

Wild, M. (2012), Enlightening Global Dimming and Brightening, Bull. Am. Meteorol. Soc., 93(1), 27-37, doi:10.1175/BAMS-D-11-00074.1.

WMO (2008), Guide to Meteorological Instruments and Methods of Observation, 7th Edition, Geneva, Switzerland.

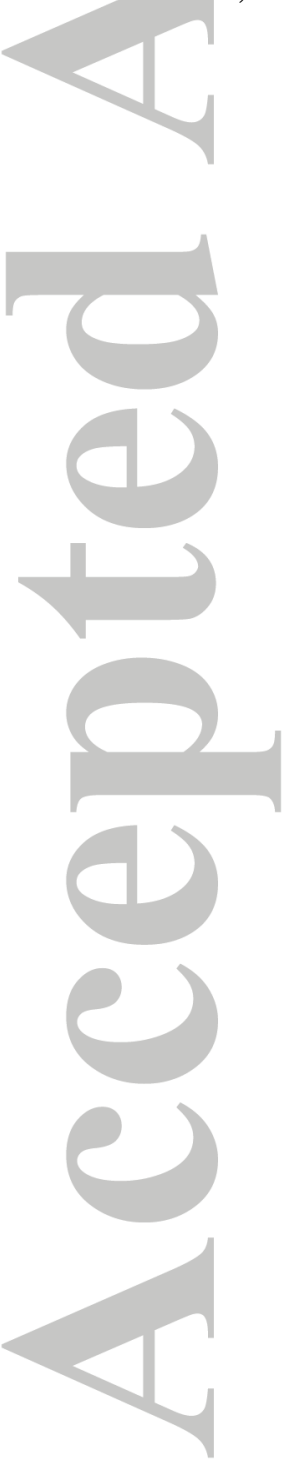




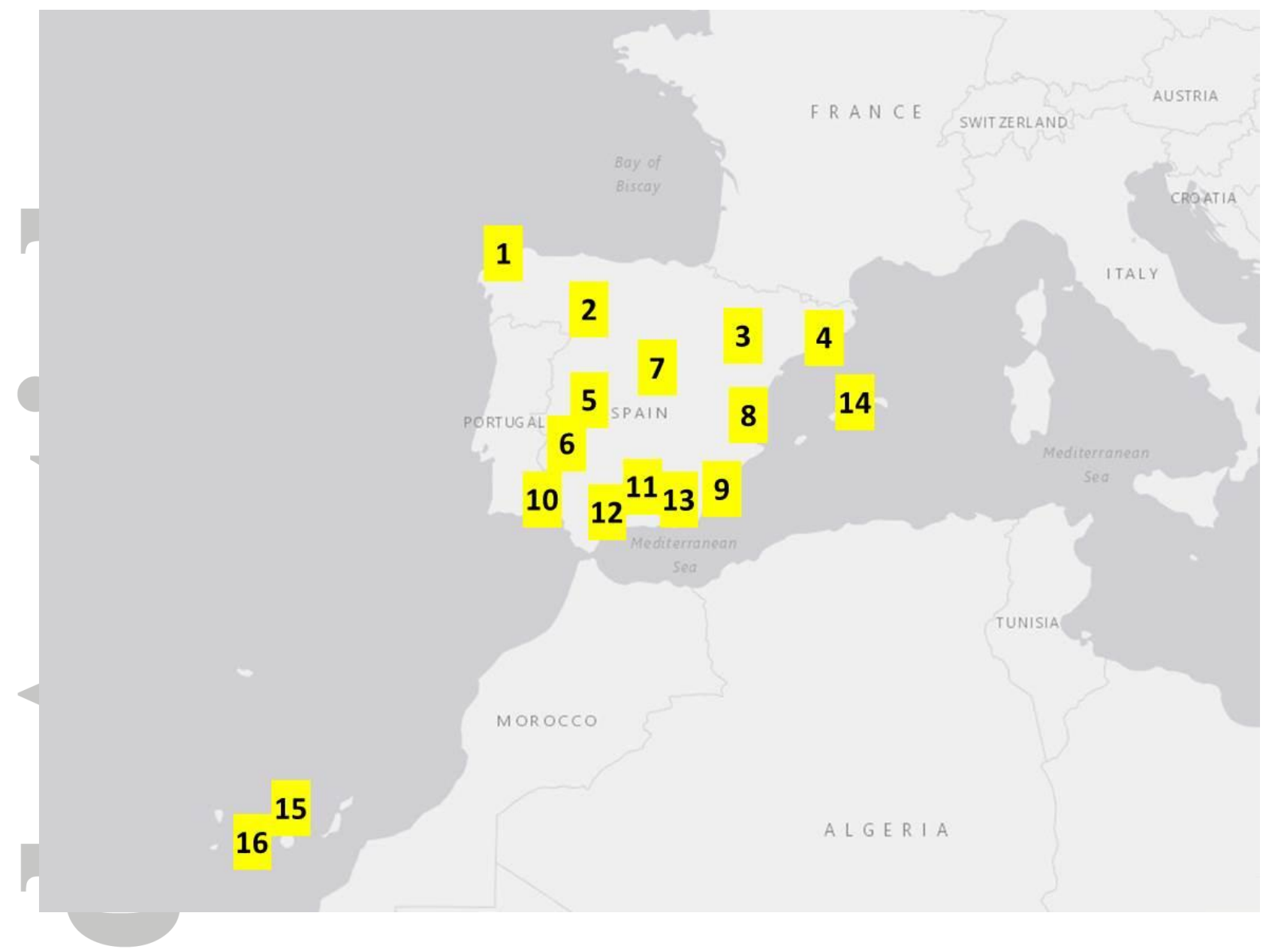

Figure 1. Map of the distribution of the 16 sites studied in our research. Each number is associated with one AEMET and one AERONET station, as defined in Table 1. 


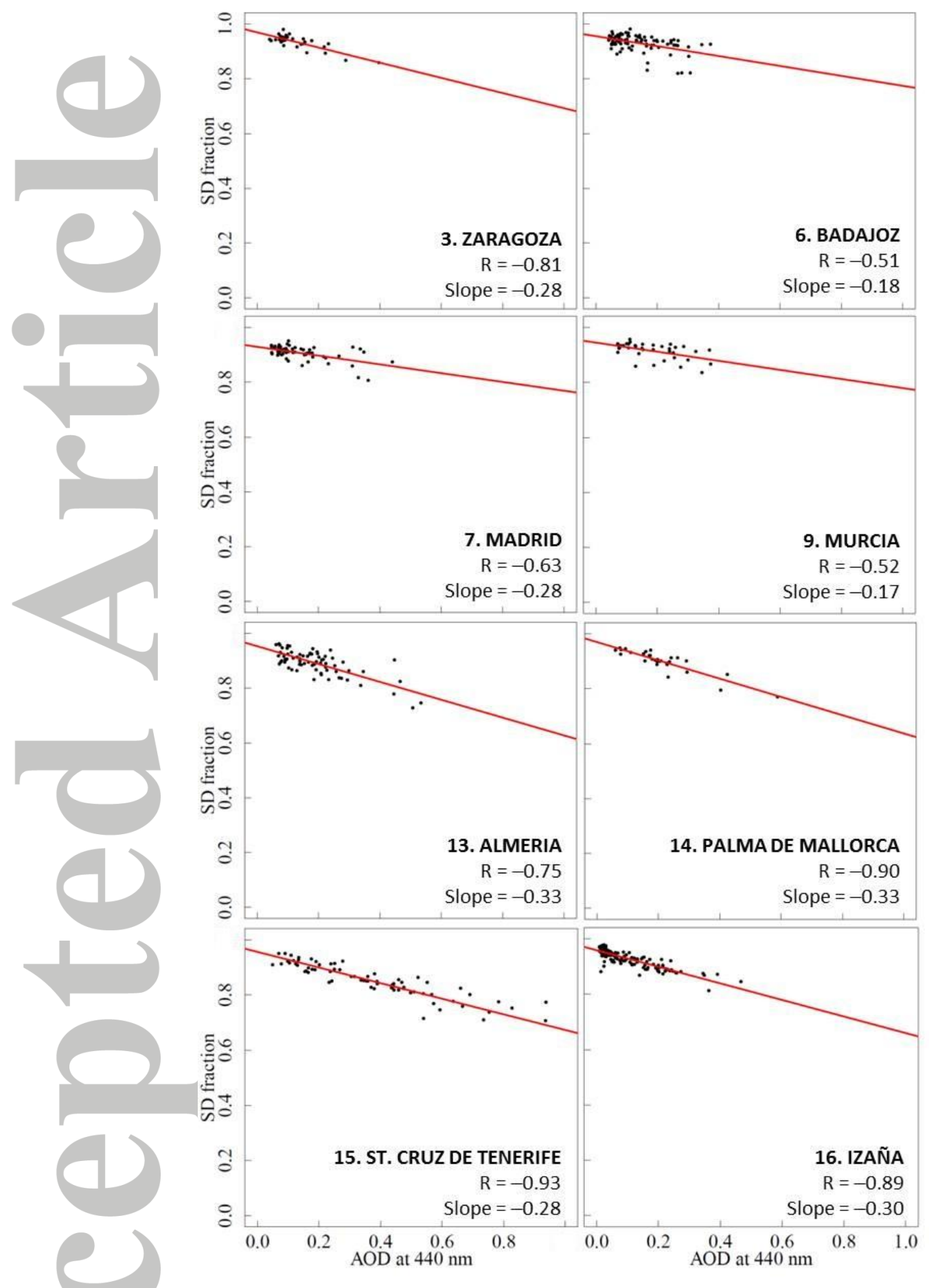

Figure 2. Scatterplots of SD fraction versus $\mathrm{AOD}_{440}$ for summer (June, July and August) at eight sites. Each point represents one day of measurements. We also show the correlation coefficient and slope values. 

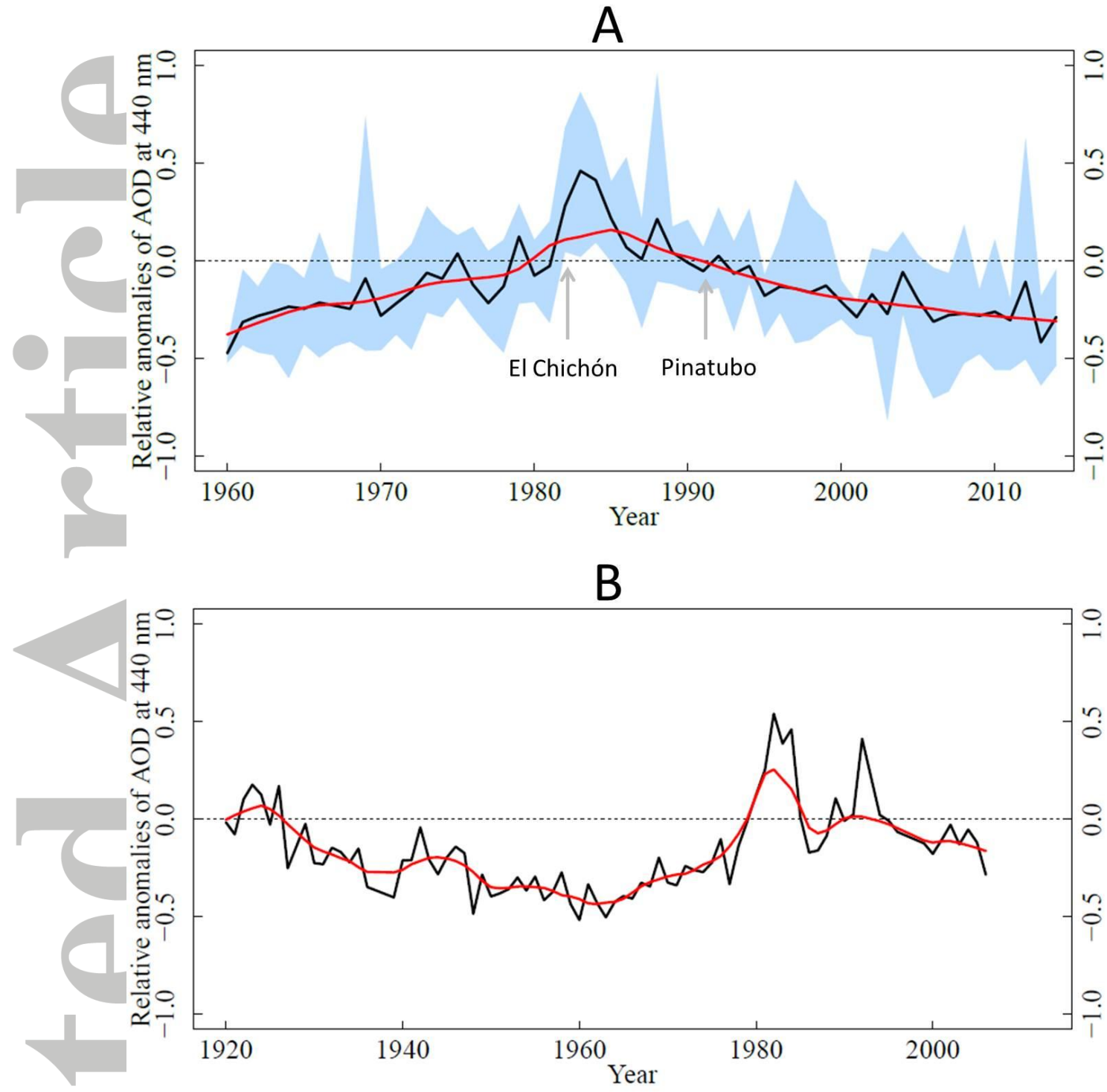

Figure 3. (A) Evolution (1961-2014 period) of the mean relative anomalies of estimated $\mathrm{AOD}_{440}$ for summer (black line) for eight sites distributed throughout Spain (including two in the Canary Isles); smoothing by a moving window of eleven years (red line) is also shown; blue area refers to range between the maximum and minimum values of the different series for each year. (B) Evolution (1920-2007 period) of the relative anomalies of estimated AOD at $440 \mathrm{~nm}$ (black line) for Madrid in summer; smoothing by a moving window of eleven years (red line) is also shown. 


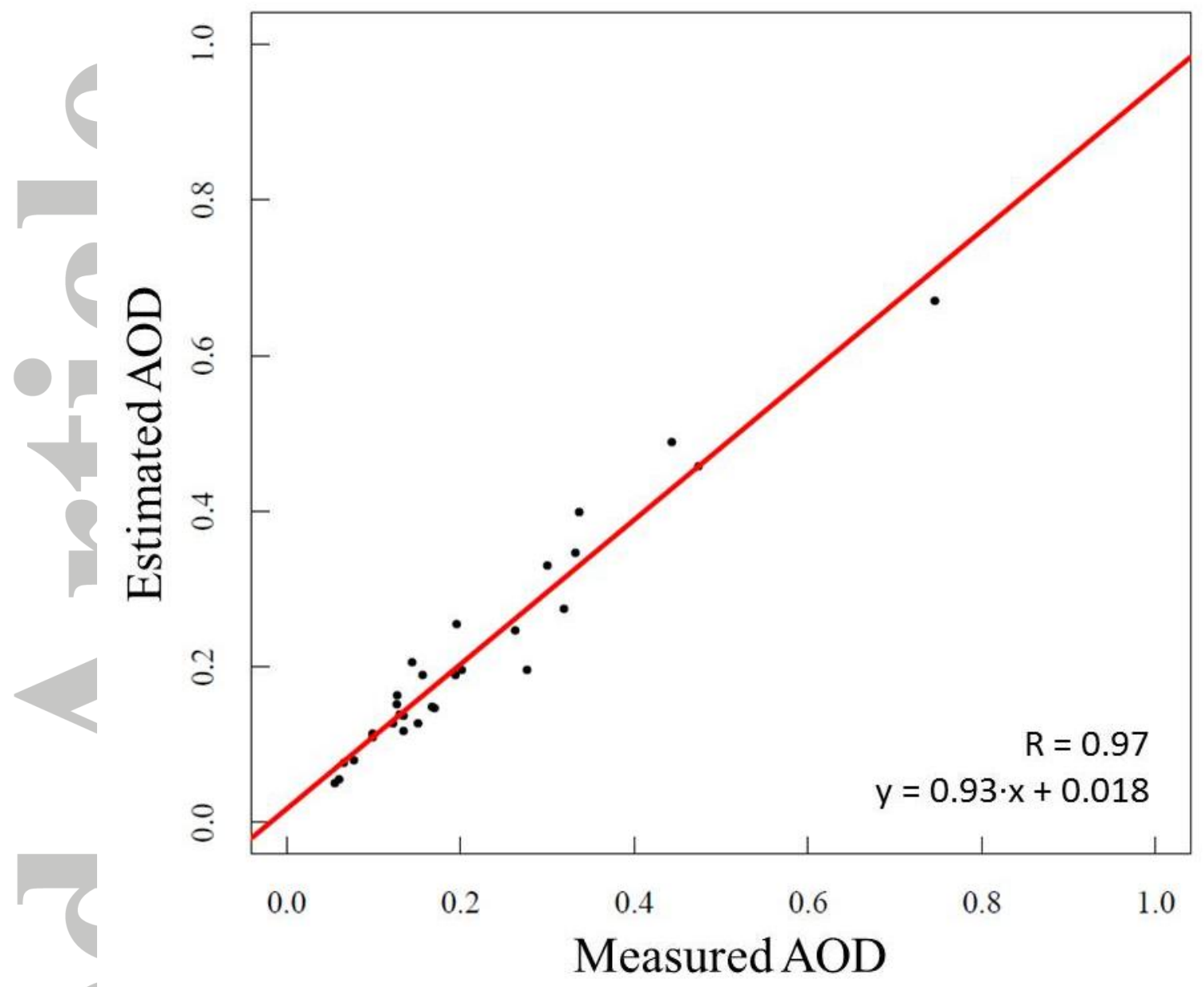

Figure S1. Scatterplot of AOD estimated from SD and AOD measured by Cimel for the eight selected stations and for summer values (average of the available days of June, July and August). Each point represents one summer mean value for one site. The fitted line and the correlation coefficient illustrate the remarkable agreement. 


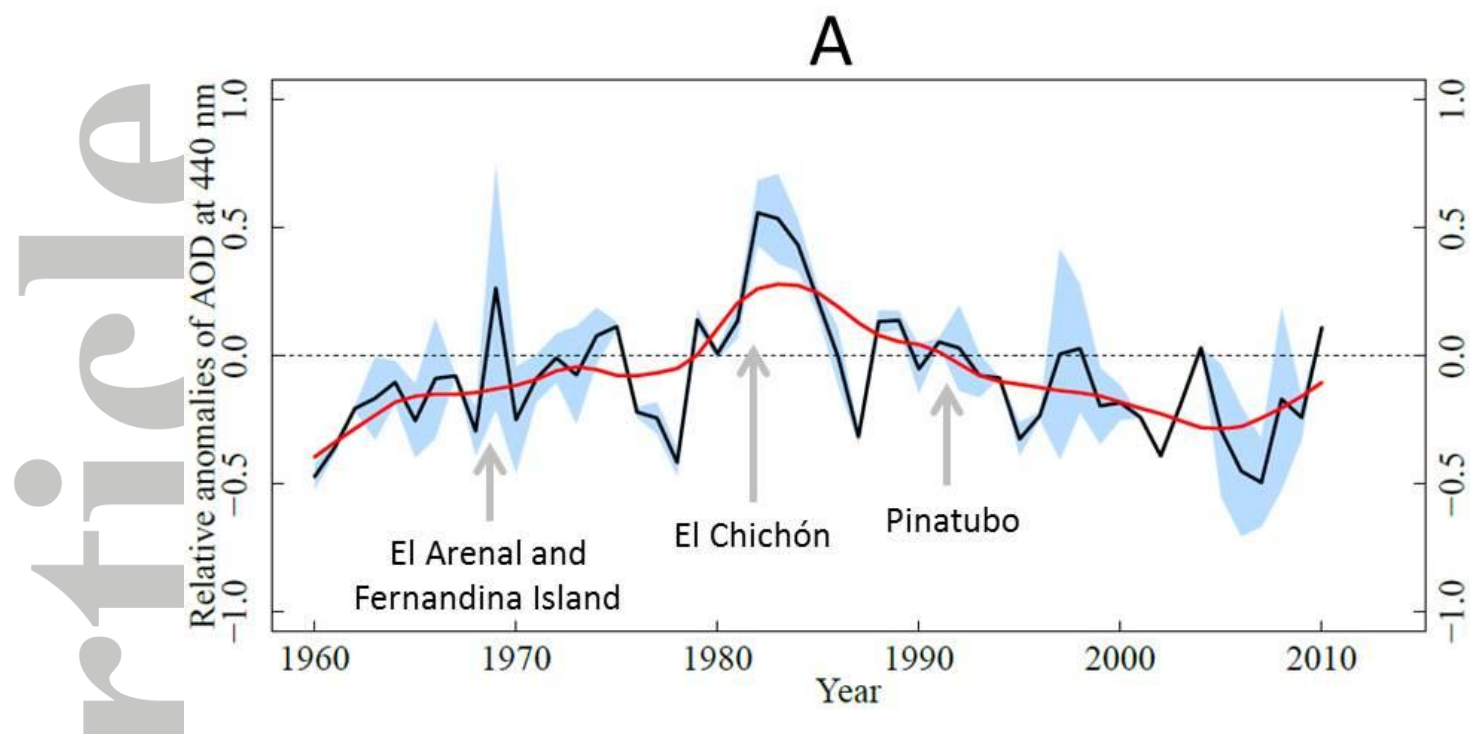

B

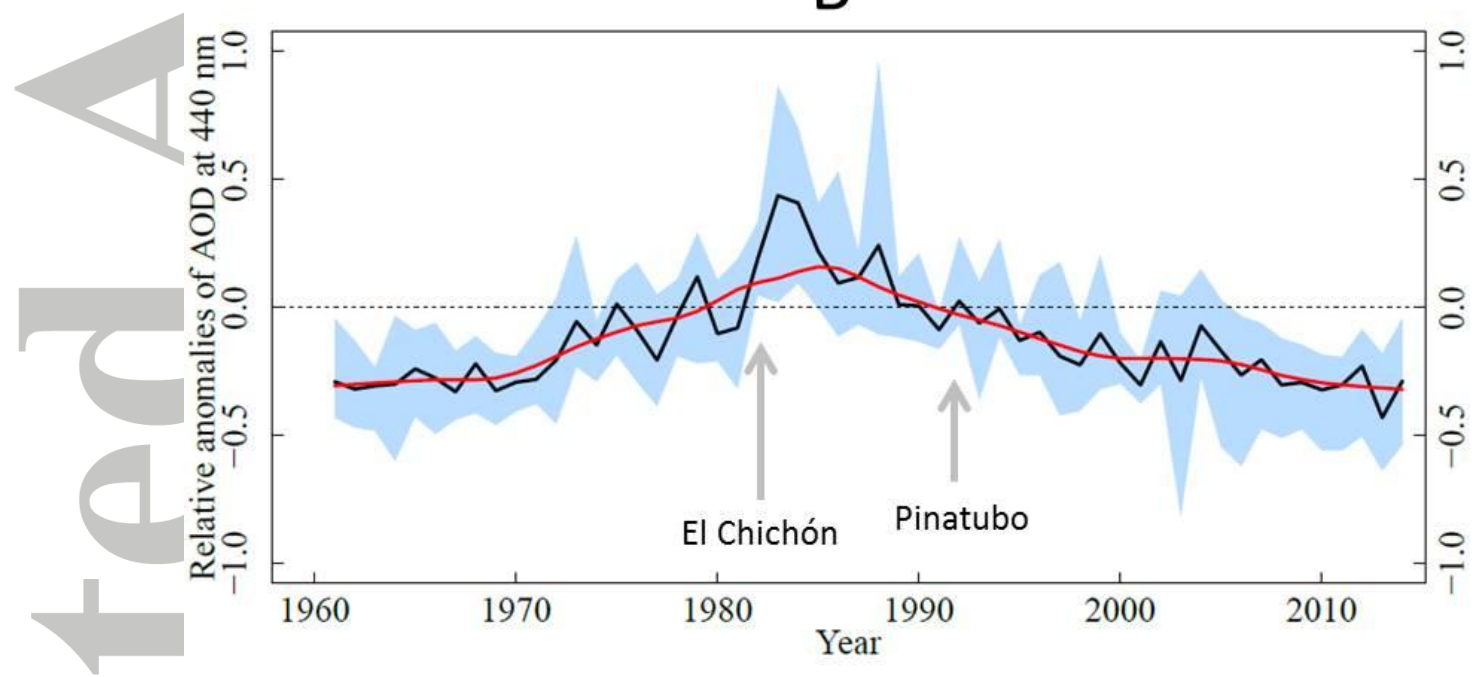

Figure S2. (A) Evolution of the mean relative anomalies of estimated $\mathrm{AOD}_{440}$ for summer for the two Canary Isles sites (1961-2014 period, black line). (B) Evolution of the mean relative anomalies of estimated $\mathrm{AOD}_{440}$ for summer for the six sites distributed throughout the Iberian Peninsula and Mallorca (1961-2014 period, black line). In both panels, smoothing by a moving window of eleven years (red line) is also shown; blue area refers to the range between the maximum and minimum values of the different series for each year.

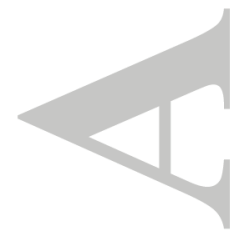


Table 1. Summary of locations of the 16 stations in Spain. For each station, latitude, longitude and elevation above sea level are specified, as well as the distance between AEMET and AERONET station. The initial date for historic SD and TCC that is available and the period used for establishing the relationships are also specified. $\mathrm{N}$ is the number of days used (only summer cloudless days) and R is the correlation coefficient between SD and AOD. In SD vs AOD columns, we include intercept and slope of the linear regression of SD fraction depending on daily $\mathrm{AOD}_{440}$. In AOD vs SD columns, we include intercept and slope of the linear regression of daily $\mathrm{AOD}_{440}$ depending on SD fraction for the 8 sites used in the long-term reconstruction of AOD. The uncertainty in the regression parameters (shown in parentheses) is calculated as their standard errors. RMSD refers to root mean square deviation between estimated and observed $\mathrm{AOD}_{440}$.

\begin{tabular}{|c|c|c|c|c|c|c|c|c|c|c|c|c|}
\hline \multirow{2}{*}{$\#$} & \multirow{2}{*}{ AEMET (SD) } & \multirow{2}{*}{ Started } & \multirow{2}{*}{ AERONET (AOD) } & \multirow{2}{*}{$\begin{array}{l}\text { Dist. } \\
(\mathbf{k m})\end{array}$} & \multirow{2}{*}{$\begin{array}{l}\text { Period } \\
\text { time }\end{array}$} & \multirow{2}{*}{$\mathbf{N}$} & \multirow{2}{*}{$\mathbf{R}$} & \multicolumn{2}{|c|}{ SD vs AOD } & \multicolumn{3}{|c|}{ AOD vs SD } \\
\hline & & & & & & & & Intercept & Slope & Intercept & Slope & RMSD \\
\hline 1 & $\begin{array}{c}\text { Coruña }^{(1)} \\
43.37^{\circ} \mathrm{N}, 8.42^{\circ} \mathrm{W}, 58 \mathrm{~m}\end{array}$ & $01 / 1961$ & $\begin{array}{c}\text { Coruña } \\
43.63^{\circ} \mathrm{N}, 8.42^{\circ} \mathrm{W}, 67 \mathrm{~m}\end{array}$ & 28.9 & $\begin{array}{c}01 / 2012 \\
- \\
03 / 2014\end{array}$ & 16 & -0.48 (NS) & $\begin{array}{c}0.962 \\
(0.018)\end{array}$ & $\begin{array}{l}-0.16 \\
(0.08)\end{array}$ & - & - & - \\
\hline 2 & $\begin{array}{l}\text { Valladolid (Villanubla) }{ }^{(1)} \\
41.70^{\circ} \mathrm{N}, 4.85^{\circ} \mathrm{W}, 846 \mathrm{~m}\end{array}$ & $01 / 1961$ & $\begin{array}{c}\text { Palencia }^{(\mathrm{r})} \\
41.99^{\circ} \mathrm{N}, 4.52^{\circ} \mathrm{W}, 750 \mathrm{~m}\end{array}$ & 42.3 & $\begin{array}{c}02 / 2003 \\
- \\
12 / 2014\end{array}$ & 146 & $-0.48(\mathrm{~S})$ & $\begin{array}{c}0.959 \\
(0.004)\end{array}$ & $\begin{array}{l}-0.20 \\
(0.03)\end{array}$ & - & - & - \\
\hline 3 & $\begin{array}{c}\text { Zaragoza (Airport) }{ }^{(1)} \\
41.66^{\circ} \mathrm{N}, 1.01^{\circ} \mathrm{W}, 247 \mathrm{~m}\end{array}$ & $01 / 1961$ & $\begin{array}{c}\text { Zaragoza } \\
41.63^{\circ} \mathrm{N}, 0.88^{\circ} \mathrm{W}, 250 \mathrm{~m}\end{array}$ & 11.3 & $\begin{array}{c}06 / 2012 \\
- \\
07 / 2014\end{array}$ & 30 & $-0.81(\mathrm{~S})$ & $\begin{array}{c}0.971 \\
(0.006)\end{array}$ & $\begin{array}{l}-0.28 \\
(0.04)\end{array}$ & $\begin{array}{c}2.33 \\
(0.30)\end{array}$ & $\begin{array}{l}-2.36 \\
(0.32)\end{array}$ & 0.045 \\
\hline 4 & $\begin{array}{l}\text { Barcelona (Fabra Obs. })^{(1)} \\
41.42^{\circ} \mathrm{N}, 2.12^{\circ} \mathrm{E}, 412 \mathrm{~m}\end{array}$ & $01 / 1983$ & $\begin{array}{c}\text { Barcelona }^{(\mathrm{u})} \\
41.39^{\circ} \mathrm{N}, 2.12^{\circ} \mathrm{E}, 125 \mathrm{~m}\end{array}$ & 3.3 & $\begin{array}{c}01 / 2005 \\
- \\
01 / 2015\end{array}$ & 21 & $-0.75(\mathrm{~S})$ & $\begin{array}{c}0.932 \\
(0.009)\end{array}$ & $\begin{array}{l}-0.15 \\
(0.03)\end{array}$ & - & - & - \\
\hline 5 & $\begin{array}{c}\text { Caceres }^{(3)} \\
39.50^{\circ} \mathrm{N}, 6.37^{\circ} \mathrm{W}, 459 \mathrm{~m}\end{array}$ & $01 / 1983$ & $\begin{array}{c}\text { Cáceres }^{(\mathrm{r})} \\
39.48^{\circ} \mathrm{N}, 6.34^{\circ} \mathrm{W}, 397 \mathrm{~m}\end{array}$ & 3.4 & $\begin{array}{c}07 / 2005 \\
- \\
06 / 2012\end{array}$ & 142 & $-0.59(\mathrm{~S})$ & $\begin{array}{c}0.948 \\
(0.003)\end{array}$ & $\begin{array}{l}-0.19 \\
(0.02)\end{array}$ & - & - & - \\
\hline 6 & $\begin{array}{c}\text { Badajoz (Talavera la } \\
\text { Real) }^{(1)} \\
38.83^{\circ} \mathrm{N}, 6.83^{\circ} \mathrm{W}, 185 \mathrm{~m}\end{array}$ & $01 / 1961$ & $\begin{array}{c}\text { Badajoz }^{(\mathrm{r})} \\
38.88^{\circ} \mathrm{N}, 7.01^{\circ} \mathrm{W}, 186 \mathrm{~m}\end{array}$ & 16.5 & $\begin{array}{c}06 / 2012 \\
- \\
10 / 2014\end{array}$ & 87 & $-0.51(\mathrm{~S})$ & $\begin{array}{c}0.961 \\
(0.006)\end{array}$ & $\begin{array}{l}-0.18 \\
(0.03)\end{array}$ & $\begin{array}{c}1.24 \\
(0.22)\end{array}$ & $\begin{array}{l}-1.18 \\
(0.24)\end{array}$ & 0.071 \\
\hline 7 & $\begin{array}{c}\text { Madrid (Cuatro Vientos) })^{(1)} \\
40.38^{\circ} \mathrm{N}, 3.79^{\circ} \mathrm{W}, 687 \mathrm{~m}\end{array}$ & $01 / 1961$ & $\begin{array}{c}\text { Madrid }^{(\mathrm{u})} \\
40.45^{\circ} \mathrm{N}, 3.72^{\circ} \mathrm{W}, 680 \mathrm{~m}\end{array}$ & 13.7 & $\begin{array}{c}03 / 2012 \\
- \\
05 / 2014\end{array}$ & 63 & $-0.63(\mathrm{~S})$ & $\begin{array}{c}0.942 \\
(0.005)\end{array}$ & $\begin{array}{l}-0.28 \\
(0.03)\end{array}$ & $\begin{array}{l}1.96 \\
(0.34)\end{array}$ & $\begin{array}{c}-2.01 \\
()\end{array}$ & 0.074 \\
\hline 8 & $\begin{array}{c}\text { Valencia }^{(3)} \\
39.48^{\circ} \mathrm{N}, 0.37^{\circ} \mathrm{W}, 11 \mathrm{~m}\end{array}$ & $02 / 1938$ & $\begin{array}{c}\text { Burjassot } \\
39.51^{\circ} \mathrm{N}, 0.42^{\circ} \mathrm{W}, 30 \mathrm{~m}\end{array}$ & 5.4 & $\begin{array}{c}04 / 2007 \\
- \\
04 / 2013\end{array}$ & 67 & $-0.29(\mathrm{~S})$ & $\begin{array}{c}0.820 \\
(0.010)\end{array}$ & $\begin{array}{l}-0.11 \\
(0.04)\end{array}$ & - & - & - \\
\hline 9 & $\begin{array}{c}\text { Murcia }^{(3)} \\
38.00^{\circ} \mathrm{N}, 1.17^{\circ} \mathrm{W}, 61 \mathrm{~m}\end{array}$ & 01/1961 & $\begin{array}{c}\operatorname{Murcia}^{(\mathrm{r})} \\
38.00^{\circ} \mathrm{N}, 1.17^{\circ} \mathrm{W}, 69 \mathrm{~m}\end{array}$ & 0.0 & $\begin{array}{c}09 / 2012 \\
- \\
10 / 2014\end{array}$ & 37 & $-0.52(\mathrm{~S})$ & $\begin{array}{c}0.938 \\
(0.009)\end{array}$ & $\begin{array}{l}-0.17 \\
(0.03)\end{array}$ & $\begin{array}{c}1.67 \\
(0.31)\end{array}$ & $\begin{array}{l}-1.62 \\
(0.45)\end{array}$ & 0.077 \\
\hline 10 & $\begin{array}{l}\text { Huelva (Ronda del Este) })^{(3)} \\
37.28^{\circ} \mathrm{N}, 6.91^{\circ} \mathrm{W}, 19 \mathrm{~m}\end{array}$ & $01 / 1960$ & $\begin{array}{c}\text { El Arenosillo }{ }^{(\mathrm{r})} \\
37.11^{\circ} \mathrm{N}, 6.73^{\circ} \mathrm{W}, 0 \mathrm{~m}\end{array}$ & 24.7 & $\begin{array}{l}02 / 2000 \\
- \\
12 / 2009\end{array}$ & 210 & $-0.67(\mathrm{~S})$ & $\begin{array}{c}0.949 \\
(0.004)\end{array}$ & $\begin{array}{l}-0.21 \\
(0.02)\end{array}$ & - & - & - \\
\hline 11 & $\begin{array}{c}\text { Granada (Airport) }{ }^{(1)} \\
37.19^{\circ} \mathrm{N}, 3.79^{\circ} \mathrm{W}, 567 \mathrm{~m}\end{array}$ & $11 / 1972$ & $\begin{array}{c}\text { Granada } \\
37.16^{\circ} \mathrm{N}, 3.60^{\circ} \mathrm{W}, 680 \mathrm{~m}\end{array}$ & 17.1 & $\begin{array}{c}12 / 2004 \\
- \\
06 / 2013\end{array}$ & 161 & $-0.92(\mathrm{~S})$ & $\begin{array}{c}0.950 \\
(0.002)\end{array}$ & $\begin{array}{l}-0.36 \\
(0.01)\end{array}$ & - & - & - \\
\hline 12 & $\begin{array}{c}\text { Malaga (Airport) })^{(1)} \\
36.67^{\circ} \mathrm{N}, 4.49^{\circ} \mathrm{W}, 7 \mathrm{~m}\end{array}$ & $12 / 1947$ & $\begin{array}{c}\text { Málaga } \\
36.72^{\circ} \mathrm{N}, 4.48^{\circ} \mathrm{W}, 40 \mathrm{~m}\end{array}$ & 5.6 & $\begin{array}{c}02 / 2009 \\
- \\
09 / 2013\end{array}$ & 143 & $-0.71(\mathrm{~S})$ & $\begin{array}{c}0.941 \\
(0.005)\end{array}$ & $\begin{array}{l}-0.25 \\
(0.02)\end{array}$ & - & - & - \\
\hline 13 & $\begin{array}{c}\text { Almeria (Airpot) }{ }^{(1)} \\
36.85^{\circ} \mathrm{N}, 2.36^{\circ} \mathrm{W}, 21 \mathrm{~m}\end{array}$ & $02 / 1968$ & $\begin{array}{c}\text { Tabernas (PSA-DLR) }{ }^{(\mathrm{r})} \\
37.09^{\circ} \mathrm{N}, 2.36^{\circ} \mathrm{W}, 500 \mathrm{~m}\end{array}$ & 26.7 & $\begin{array}{c}02 / 2011 \\
- \\
10 / 2014\end{array}$ & 73 & $-0.75(\mathrm{~S})$ & $\begin{array}{c}0.952 \\
(0.007)\end{array}$ & $\begin{array}{l}-0.33 \\
(0.03)\end{array}$ & $\begin{array}{c}1.72 \\
(0.16)\end{array}$ & $\begin{array}{l}-1.72 \\
(0.18)\end{array}$ & 0.067 \\
\hline 14 & $\begin{array}{c}\text { Palma de Mallorca } \\
(\mathrm{CMT})^{(3)} \\
39.56^{\circ} \mathrm{N}, 2.63^{\circ} \mathrm{E}, 3 \mathrm{~m}\end{array}$ & 08/1972 & $\begin{array}{c}\text { Palma de Mallorca } \\
39.55^{\circ} \mathrm{N}, 2.63^{\circ} \mathrm{E}, 10 \mathrm{~m}\end{array}$ & 1.1 & $\begin{array}{c}08 / 2011 \\
- \\
12 / 2013\end{array}$ & 31 & $-0.90(\mathrm{~S})$ & $\begin{array}{c}0.970 \\
(0.007)\end{array}$ & $\begin{array}{l}-0.33 \\
(0.03)\end{array}$ & $\begin{array}{c}2.39 \\
(0.20)\end{array}$ & $\begin{array}{l}-2.42 \\
(0.22)\end{array}$ & 0.047 \\
\hline
\end{tabular}


Sta. Cruz de Tenerife ${ }^{(3)}$

Sta. Cruz de Tenerife ${ }^{(\mathrm{m})}$

1.5

07/2005

Izaña $^{(2)}$

$16 \quad 28.31^{\circ} \mathrm{N}, 16.50^{\circ} \mathrm{W}, 2371$

$01 / 1920$

Izaña $^{(\mathrm{m})}$

$\mathrm{m}$

$28.31^{\circ} \mathrm{N}, 16.50^{\circ} \mathrm{W}, 2391 \mathrm{~m}$

0.0

$02 / 2014$

$01 / 2005$

(rin

(1) Stations which still measure SD with CSSR. (2) Station where CSSR has been replaced with automatic sensors (Izaña 2001). (3) Stations where the instrument may have been changed, but for which this information is unavailable.

(u) Urban site. (r) Rural site. (m) Marine site, i.e. island

(S) Correlation coefficient is statistically significant at a confidence level higher than 95\%. (NS) Correlation coefficient is not statistically significant with the same level.
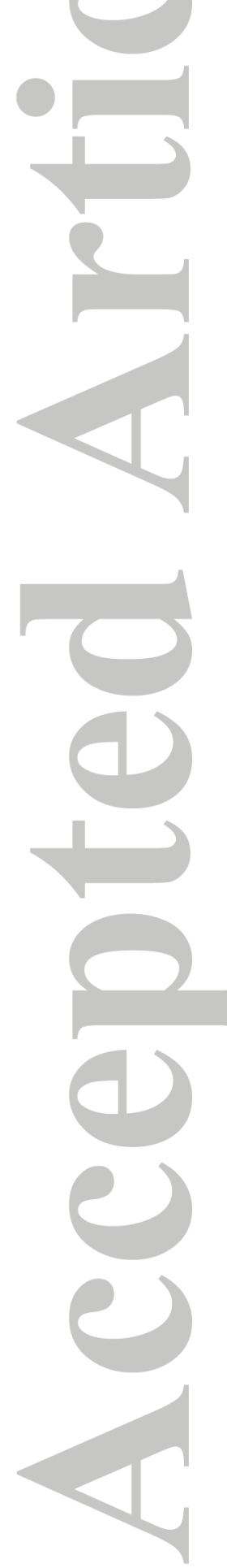
Table S1. Reconstructed time series of average summer AOD for Spain from 1961 to 2014, obtained from 8 sites distributed throughout Spain (including two in the Canary Isles).

\begin{tabular}{|c|c|c|c|c|c|c|c|c|c|c|c|}
\hline Year & AOD & Year & AOD & Year & AOD & Year & AOD & Year & AOD & Year & AOD \\
\hline 1961 & 0.08 & 1971 & 0.20 & 1981 & 0.23 & 1991 & 0.22 & 2001 & 0.12 & 2011 & 0.09 \\
\hline 1962 & 0.09 & 1972 & 0.19 & 1982 & 0.34 & 1992 & 0.26 & 2002 & 0.17 & 2012 & 0.20 \\
\hline 1963 & 0.10 & 1973 & 0.20 & 1983 & 0.42 & 1993 & 0.22 & 2003 & 0.13 & 2013 & 0.09 \\
\hline 1964 & 0.12 & 1974 & 0.20 & 1984 & 0.39 & 1994 & 0.22 & 2004 & 0.21 & 2014 & 0.10 \\
\hline 1965 & 0.11 & 1975 & 0.26 & 1985 & 0.29 & 1995 & 0.18 & 2005 & 0.19 & & \\
\hline 1966 & 0.11 & 1976 & 0.20 & 1986 & 0.24 & 1996 & 0.20 & 2006 & 0.14 & \\
\hline 1967 & 0.09 & 1977 & 0.17 & 1987 & 0.25 & 1997 & 0.19 & 2007 & 0.13 & \\
\hline 1968 & 0.13 & 1978 & 0.28 & 1988 & 0.30 & 1998 & 0.18 & 2008 & 0.15 & \\
\hline 1969 & 0.22 & 1979 & 0.30 & 1989 & 0.24 & 1999 & 0.19 & 2009 & 0.13 & \\
\hline 1970 & 0.13 & 1980 & 0.20 & 1990 & 0.23 & 2000 & 0.15 & 2010 & 0.13 \\
\hline
\end{tabular}

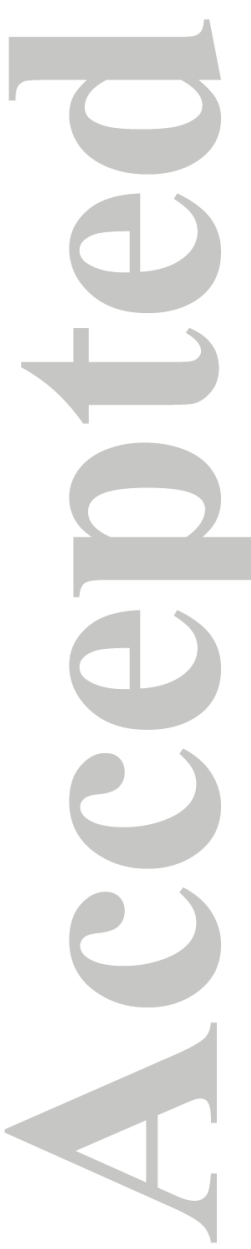

